\title{
Kernos
}

Revue internationale et pluridisciplinaire de religion grecque antique

1 | 1988

Varia

\section{A Hellenistic Legacy: The Foundation for an 'Unorthodox' World View within the Byzantine Tradition}

\section{J.B. McMinn}

\section{(2) OpenEdition}

\section{Journals}

Electronic version

URL: http://journals.openedition.org/kernos/83

DOI: $10.4000 /$ kernos.83

ISSN: 2034-7871

\section{Publisher}

Centre international d'étude de la religion grecque antique

Printed version

Date of publication: 1 January 1988

ISSN: 0776-3824

\section{Electronic reference}

J.B. McMinn, «A Hellenistic Legacy: The Foundation for an 'Unorthodox' World View within the Byzantine Tradition », Kernos [Online], 1 | 1988, Online since 31 January 2011, connection on 01 May 2019. URL : http://journals.openedition.org/kernos/83 ; DOI : 10.4000/kernos.83 


\title{
A HELLENISTIC LEGACY : THE FOUNDATION FOR AN 'UNORTHODOX' WORLD, VIEW WITHIN BYZANTINE TRADITION
}

\author{
(part one)
}

On one historical point almost all historians of Byzantine civilization are generally agreed, namely, that external changes in the East during the time of the Emperor Justinian pose the question of survival of late antiquity and its tradition in the new Byzantine world. In fact, they make the explicit claim that with the rise of the monastic movement, the army reform, the closure of the universities, and the expansion of the Arabs, the influence of Hellenistic culture as a dominating force in Byzantine life comes to an end ${ }^{1}$. And, as

1 H.W. HAUSSIG, A History of Byzantine Civilization, trans. J.M. Hussey, New York, 1971, p. 48-49, 74, 76-90,115, 121-128, and 210-233. More than other historians, HAUSSIG (op. cit., p. 75) presses his point: «The age of Justinian is essentially the time of transition from the world of late antiquity [Hellenistic period] to that of Byzantium [...]». Corroborating this cultural breach for one or more of the reasons listed above are the following historians of Byzantine civilization : G. FINLAY, A History of Greece, I, Oxford, 1877, p. 277-287; W.G. HOLMES, The Age of Justinian and Theodora: A History of the Sixth Century A.D., II, London, 1907, p. 438439; J.B. BURY, History of the Later Roman Empire, II, London, 1923, p. 367-370; Ch. DIEHL, History of the Byzantine Empire, trans. G.B. Ives, Princeton, 1925, p. 12-16, 17-39, and 40; A.A. VASILIEV, History of the Byzantine Empire, I, trans. Mrs S. Ragozin, Madison, 1928, p. 174, 184; J. LINDSAY, Byzantine into Europe, London, 1952, p. 261-267; S. RUNCIMAN, Byzantine Civilization, London, 1966, p. 254-269; J.W. BARKER, Justinian and the Later Roman Empire, Madison, 1966, p. 208-210; G. OSTROGORSKY, History of the Byzantine State, trans. J. Hussey, rev. ed., New Brunswick, 1969, p. 77; D.J. GEANAKOPLOS, Interaction of the "Sibling" Byzantine and Western Cultures in the Middle Ages and Italian Renaissance (330-1600), New Haven, 1976, p. 39-43; C. MANGO Byzantium: The Empire of New Rome, New York, 1980, p. 4-5; N. CHEETHAM, Mediaeval Greece, New Haven, 1981, p. 1-23. - The only historian taking the opposite view, and with whom I agree, is Norman Hepbum BAYNES (N.H. BAYNES and H.St.L.B. MOSS, Byzantium : An Introduction to East Roman Civilization, Oxford, 1948, p.xviii-xx; N.H. BAYNES, Byzantine Studies and other Essays, London, 1955, p. 1-23, $47-48,70-72$, and 168-172, where he speaks time and again of the Byzantines as heirs of Hellenistic civilization). - In respect of political thought, $\mathrm{Sir}$ Emest BARKER (Social and Political Thought in Byzantium from Justinian I 
one would expect, the evidence seems to justify this claim. There is, however, entailed in this supposed cultural terminus, a matter of philosophical significance which, I think, raises a question about the wholesale disposal of this cultural influence. It is the alleged rejection of Hellenistic cosmology ${ }^{2}$. This comes about, historians claim, as a consequence of the emergence of icon veneration (i.e., icons revered as receptacles of divine power) and the concomitant burgeoning of ecclesiastical art, both inspired by the monastic movement ${ }^{3}$. While not themselves effecting this change, these cultural phenomena provide the occasion for a fundamental shift in the Byzantine conception of the universe ${ }^{4}$. Hans-Wilhelm Haussig, a contemporary German historian, offers what seems to be a typical explanation of this transition :

The iconographic programme and the form of the interior of a church were not determined only by the adoption of the icon and its artistic

to the late Paleologus, Oxford, 1957, p. 1-25) agrees with BAYNES that Byzantium preserves and cherishes the inherited political theory of ancient Greece, both Hellenic and Hellenistic. David T. RICE (The Byzantines, New York, 1962 , p. 30) is taking a middling position because he thinks that the evidence does not support either extreme view.

2 HAUSSIG, op. cit., p. 90, 187 and cf. also p. 358-359. MANGO, op. cit., p. 166, and p. 261-265. J. MEYENDORFF (Byzantine Theology: Historical Trends and Doctrinal Themes, New York, 1979, p. 23-29) questions the alleged disappearance of the Platonic world view from Byzantine Christianity, but does not pursue the matter. J. LINDSAY (op. cit., p. 264) notes the effect of a 'foreign' cosmography on art, observing that «the original idea of a new centre, round which the whole universe revolved, did not die away [...] here we touch the great new formative principle which Byzantine art brings into being.»

3 HAUSSIG, op. cit., p. 84-85; MANGO, op. cit., p. 259-270, esp. p. 261265, and p. 269-270. Here again, RICE (op. cit., p. 130-131) retreats from the homs of the argument; LINDSAY, op. cit., p. 261-267 and 270-276.

4 MANGO, op. cit., p. 151-165 and 166-176; HAUSSIG, op. cit., p. 84-90. LINDSAY (op. cit., p. 271) giving an architectural description of Saint Sophia, refers to the astrological epithet pantokrator ascribed to Christ as judge of the world. Also, commenting on the Palestine (Jewish) influence on Byzantine art, and iconography in particular, he writes (ibid., p. 267) : «The strong forms of a new attitude to life appear. The classical basis is there, but changed, stirred from its decadence into a tingling new life by the Syrian buffet [...]. The slumbering element has broken out, awake [...] and the fullness of life [...] goes [...] beyond Athenian dreams [...]". Cf. also R. BYRON, The Byzantine Achievement, New York, 1964, p. 201. D.A. MILLER (The Byzantine Tradition, New York, 1966, p. 78-83) thinks that the Byzantines were more mindful of their Hellenistic heritage in this sacred art. 
conception as represented in fresco and mosaic. Icons had already been influenced by the popular religious practices of pre-Christian Egypt, and similarly the form and subdivision of iconographic material showed non-Christian origins. In such an iconography, developed under monastic influence, Hellenistic cosmology was abandoned. The world was no longer represented as a sphere with a single heavenly space, but an eastern cosmology of the heavens was adopted, and in particular an old Jewish conception, which thought that there were several heavens and corresponded to an Akkadian-Chaldean tradition, now found expression in the monastic movement. ${ }^{5}$. [Italics mine]

To be sure, Haussig's explanation is not without its truth. It is the case that iconography appears in earlier pre-Christian cultures, largely among the popular religious cults in Egypt and Anatolia, and that in some instances Byzantine icons bear this earlier stamp, particularly of some astrological aspect. It is also true that there is a 'Christian' adaptation of an inherited cosmography, 'encouraged' by the strictures of the monastic cadre, in which the spherical heavens are at times pictured under domes and that this inherited cosmography reflects Mesopotamian sources, in all likelihood traces of the Chaldean tradition. But what I take exception to is that these astral features are treated as discrete borrowings of alien elements, whether of Akkadian, Chaldean, Jewish, or 'Christian' apocryphal origin, and that these transmissions constitute a forsaking of an ancient Greek patrimony. Furthermore, Haussig's comprehension of Hellenistic cosmology, and that of other historians as well, is much too narrow and restrictive for his argument to be admissible, much less persuasive ${ }^{6}$. To identify this cosmology simply as Platonic or, latterly, neo-Platonic is too simplistic. Even a casual review of its content during the late antique period will show much more than a neo-Platonic connection. Indeed, one will find in this cosmology an amalgam of 'foreign' elements, precisely those which Haussig and others have alleged filtered into the emerging Byzantine culture

5 HAUSSIG, op. cit., p. 90. R.K. DEKOSKY (Knowledge and Cosmos : Development and Decline. of the Medieval Perspective, Washington, 1979, p. 6571) shows that Neo-Platonism was compatible with an astrological world view and that astrological causation was characteristic of this cosmology. Cf. also D.R. DICKS, Early Greek Astronomy to Aristotle, Ithaca, 1970, p. 218-219. 
piecemeal from the provinces? ${ }^{7}$ It is my contention that, far from abandoning Hellenistic cosmology, the Byzantine artist cosmographer finds all these astral features ready to hand in the syncretistic world views ${ }^{8}$ of the later Hellenistic age and appropriates them being the Hellenist that he is - without scruple of their 'foreign' character, for use in his own 'Christian' schema.

How this cosmology is spelled out in Hellenistic times becomes, I claim, the pagan option for an 'unorthodox' Byzantine world view. To show, then, that all the astral (pagan) features, which Haussig and others claim to have come from separate pagan sources, are to be found in the late antique Hellenistic cosmology, I shall reconstruct in synoptic fashion this cosmic theory according to its two popular religious expressions : the Stoic and the Gnostic world views?.

7 HAUSSIG, op. cit., p. 35-40; BYRON, op. cit., p. 54-57. Cf. Ch. DIEHLS, Byzantine Art, in BAYNES and MOSS, op. cit. (n. 1), p. 169-170, 176-178, and 185-186; also LINDSAY, op. cit., p. 216-267. - Yet LINDSAY (op. cit., p. 19) warns against calling the movement eastward 'orientalisation' or taking the changes to be a sign of 'oriental influences' because they suggest, as scholars have used them, the prejudice of moral collapse.

The popular Hellenistic world views are a kaleidoscopic synthesis of Greek philosophy, Chaldean astrology, and oriental religion, a composite which becomes more theological than philosophical. In Early Stoicism, Epicureanism, and Plotinianism, purer philosophical world views appear, but none of these systems achieves a wide acceptance in Hellenistic times; cf. E. CAIRD, The Evolution of Theology in the Greek Philosophers, II, Glasgow, 1904, p. 59. Those systems or cults sharing in the Stoic world view are Posidonian Stoicism, Neo-Pythagoreanism, Orphism, Emperor Worship, and Mithraism. Those sharing in the gnostic world view are Hermeticism, Gnosticism, Pauline Christianity, Serapism, and Neo-Platonism. Perhaps no distinction should really be made between Hermeticism and NeoPlatonism, since the Hermetic world view in most instances is identical with that of later Neo-Platonists. For a review of this syncretistic tendency, vide J.B. McMINN, Fusion of the Gods : A Religio-Astrological Study of the Interpretation of the East and West in Asia Minor, in JNES, 15(1956), p. 201-213. Vide also J.B. McMINN, The Astrological Significance of the

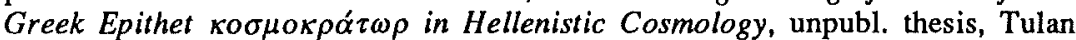
Univ., New Orleans, 1960; ID., An Historical Treatment of the Greek Phrase

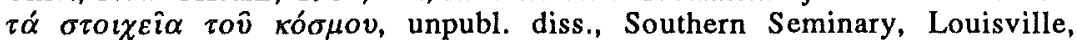
Kentucky, 1950; G. DE SANTILLANA and H. von DECHEND, Hamlet's Mill: An Essay on Myth and the Frame of Time, Boston, 1969, p. 50, 64, 75, and 228; G. DE SANTILLANA, Reflections on Men and Ideas, Cambridge, Mass., 1968, p. 42, 44, 46, and 119; R. THIEL, And There Was Light: The Discovery of the Universe, trans R. and C. Winston, New York, 1957, p. 18-35, 56-65, and 104-108.

9 The term Stoic here refers to what is frequently called the Middle and Later Stoa : that period of Stoic philosophy which shows a marked tendency to 
Both of these 'systems' show the dominating influence of Chaldean astrology and astral mysticism, particularly, through the primacy of the planets in their dramatic roles as gods or as demonic powers ${ }^{10}$. In conclusion, I shall offer, briefly, from Byzantine historical accounts, what I consider to be evidence of this cultural influence.

\section{The Stoic World View}

«Astrology», Murray states, «[falls] upon the Hellenistic mind as a new disease falls upon some remote island people», and «every one [is] ready to receive the germ» 11 . The Stoics as a whole are the first to give way to its influence ${ }^{12}$. Already committed to a belief in the sympathy of all creation ${ }^{13}$ and to the doctrine of Necessity ${ }^{14}$,

eclecticism, admitting Platonic and oriental elements in its system and departing to this extent from the orthodox Stoicism of Zeno, Cleanthes, and Chrysippus. A few representatives are Posidonius, Cicero, Diodorus, Manilius, Seneca, Plutarch, et al;; cf. E. BEVAN, Stoics and Sceptics, Oxford, 1913, p. 85 sq., and F. COPLESTON, A History of Philosophy : Greece and Rome, I, London, 1951, p. 421-437; T.R. GLOVER, The Conflict of Religions in the Early Roman Empire, London, 1919, p. 33-112. - By the term gnostic I refer not simply to the speculative systems developing within the early Christian Church but also to those Oriental-Hellenistic syncretisms whose cosmic view offers a systematic framework of the ascent of the soul toward god, i.e., a gnosis of an itinerarium mentis ad deum summum. For this distinction of the term, vide Th. WHITTAKER, The Neo-Platonists : A study in the History of Hellenism, Cambridge, 1918, p. 218 sq., and especially D.W. BOUSETT, s.v. Gnosis, in RE, VII(1912), c. 1502-1532; ID., s.v. Gnostiker, ibid., c. 1534-1574; S. ANGUS, The Religious Quests of the Graeco-Roman World, London, 1929, p. 376-397.

10 The primacy of the planets in Hellenistic cosmology indicates its Chaldean heritage. Cf. SCOTT, Hermetica, III, p. 372.

11 MURRAY, Five Stages, p. 139; cf. BEVAN, op. cit. (n. 9), p. 115; E.R. DODDS (The Greeks and the Irrational, Boston, 1957, p. 245 sq.) takes exception to MURRAY's figure here; cf. also F. CUMONT, Astrology and Religion, p. xix, and M.P. NILSSON, A History of Greek Religion, p. 70; A.D. NOCK, Conversion, Oxford, 1952, p. 99-121.

12 As indicated in n. 9, reference here is to the Middle and Later Stoa. It could properly be called Posidonian Stoicism, as represented in Cicero's later writings. Cf. also the writings of Diodorus, Manilius, Seneca, and Plutarch; vide BEVAN, op. cit., p. 85.

13 ZENO in CIC., De Nat. Deor., III, 28; cf. also CIC., De Divinat., II, 34, 124, 142. CHRYSIPPUS (Cleomedes) in von ARNIM, Fragmenta, II, p. 170, 32.

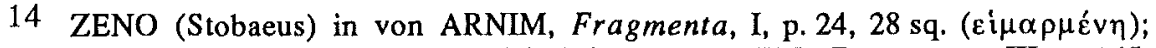
Chrysippus (Alexander Aphrodisias) in von ARNIM, Fragmenta, III, p. 165,

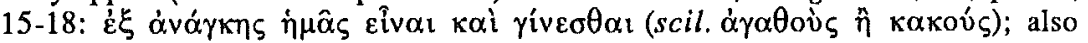
Chrysippus (Stobaeus) in von ARNIM, Fragmenta, II, p. 264, 18 sq. 
they find in the Chaldean 'science' a support to their pantheistic world view ${ }^{15}$. Astrological calculations, enhanced by a supposed antiquity, also intensify their belief in the deity of the stars ${ }^{16}$ and strengthen their general belief in prophecy and divination ${ }^{17}$. Moreover, through astrological fatalism they are able to account for the sufferings of man ${ }^{18}$; while through astral mysticism they find temporal relief from these sufferings and also the way to personal immortality ${ }^{19}$. Chaldean astrology, therefore, provides a new basis for the Stoic world view and, consequently, transforms it from a philosophical to a popular religious system ${ }^{20}$. The astrological character of this syncretistic world view appears in its pictorial descrip-

15 ZENO and CHRYSIPPUS in DIOG. LAERT., VII, 148; also in von ARNIM, Fragmenta, II, p. 305, 26 sq. ; CLEANTHES (Aetius) in von ARNIM, Fragmenta, I, p. 120, 38 sq.; also in DIELS, Doxographi, p. 302, 15.

16 CLEANTHES in CIC., De Nat. Deor., II, 40-41; ZENO in DIOG. LAERT., VII, 144 sq.

17 CIC., De Divinat., I, 6, concerning Zeno, Cleanthes, and Chrysippus. - CIC., De Divinat., II, 87 sq., indicates that all the Stoics (except Panaetius) accepted the Chaldean art of astral divination and prophecy. Vide CHRYSIPPUS in DIOG. LAERT., VII, 149.

18 MANILIUS, Astronomicon, IV, 14 sq. Cf. CUMONT, op. cit. (n. 11), p. 153 sq.; GREENE, Moira, p. 347 sq.

19 CIC., De Republ., VI, 16-19, trans. C. W. Keyes, LCL. Early Stoicism considered astral salvation as the retum to the primeval fire; e.g., CHRYSIPPUS (Arius Didymus) in von ARNIM, Fragmenta, II, p. 223, 20; also in DIELS, Doxographi, p. 471, 19-20, but cited simply as a teaching of the Stoa. Cf. PLIN., Nat. Hist., VII, 55, trans. H. Rackham, LCL.

20 Although one might reasonably claim that Stoic cosmology inherits most of its salient features from Pythagoras, Plato, and Aristotle, it seems more reasonable, however, to assert that its world view, reflecting at the beginning the philosophical character of its own culture, becomes essentially Chaldean and consequently more religious than philosophical. Those scholars who argue from the point of view of Greek influence are NILSSON, op. cit. (n. 11), p. 289-291; BEVAN, op. cit. (n. 9), p. 116; GREENE, op. cit., p. 351-354; JAEGER, Aristotle, p. 156, n. 1, 162 sq., 373 sq.; C.H. MOORE, The Religious Thought of the Greeks, Cambridge, Mass., 1925, p. 187; and E. ZELLER, Outlines of the History of Greek Philosophy, trans L.R. Palmer, London, 1950, p. 247-255. On the other hand, cf. J. BURNET, Early Greek Philosophy, London, 1952, p. 24, n. 1; F. CUMONT, After Life in Roman Paganism, New Haven, 1922, p. 30 sq.; ID., Astrology and Religion, p. 81 sq.; and S. ANGUS, The Environment of Early Christianity, London, 1914, p. 186 . 
tion of the world as a macrocosm and in its theological account of the seven planets as the rulers of the world ${ }^{21}$.

\section{The Macrocosm}

The physical order. The Stoic world is an immanent physical universe founded upon an astrological dualism of sublunary and superlunary parts ${ }^{22}$. These two parts contain graded levels of existence, extending from inorganic entities, as in the mineral kingdom, through plants and animals up to man and to the superorganic spheres of the planets and the fixed stars ${ }^{23}$. In the sublunary part there are four zones : the earth, the water, which covers a vast portion of the earth, the air of the atmosphere, and the upper region of fire ${ }^{24}$. These four zones contain the four elements from which all sublunary phenomena derive ${ }^{25}$. The composite nature of these phenomena accounts for their erratic movement and contigent existence. From the outer boundary line of the fiery zone extend the spheres of the superlunary world, viz., the seven planetary spheres and the sphere of the fixed stars. In the first and lowest of the planetary spheres is the Moon; then above the Moon come the six other planets : Mercury, Venus, the Sun, Mars, Jupiter, and Saturn. The eighth sphere, which marks the bounds of the universe, is the circle of the Zodiac and the other fixed stars ${ }^{26}$. These celestial bodies are

21 Since the extant accounts of this system are largely fragmentary, this description of the Stoic world view is drawn primarily from J. von ARNIM's Stoicorum Veterum Fragmenta and H. DIELS' Doxographi Graeci; other primary sources of the Middle and Later Stoa are used also.

22 Vide CIC., De Nat. Deor., II, 36-58, and passim; DIOG. LAERT., VII,138-160. $N$. B. a synopsis of this cosmography in AUGUST., De Civit. Dei, VII, 6; De opinione Varronis, Migne (in all likelihood the teaching of Posidonius); cf. BEVAN, op. cit., p. 43, 107; ZELLER, op. cit., p. 252; FESTUGIERE, Personal Religion, p. 105-121; COPLESTON, op. cit. (n.9), I, p. 423.

23 CIC., De Nat. Deor., II, 36. Cf. COPLESTON, op. cit., I, p. 422.

24 CIC., De Nat. Deor., I, 103-104; Posidonius in DIOG. LAERT., VII, 155 sq.; POSIDONIUS (Alexander Aphrodisias) in von ARNIM, Fragmenta, II, p. 155, 32.

25 EPICTETUS, fr. 8, trans. W. A. Oldfather, LCL; DIOG. LAERT., VII, 136-137; 142. Cf. PHILO, On the Special Laws, I, 266, trans. F.H. Colson, LCL.

26 CIC., De Nat. Deor., II, 51-53; CIC., De Republ., VI, 17-18. Cf. CHRYSIPPUS (Nemesius) in von ARNIM, Fragmenta, II, p. 190, 10 sq.; CHRYSIPPUS (Stobaeus) in von ARNIM, Fragmenta, II, p. 168, 32 sq. As regards the various ancient orderings of the planets and their distance from the earth, vide SCOTT, Hermetica, II, Oxford, 1925, p. 444-445; PHILO, Who is the Heir, 224 sq. 
composed of ether, a fifth element purer and more divine than the other four elements ${ }^{27}$; and unlike sublunary phenomena, their movement is orderly and their existence, eternal.

The psychical order. The macrocosm, however, is not simply a physical order. It is also an order of living beings, i.e., psychic centers which occupy graded levels of existence in the sublunary and superlunary spheres 28 . The ascending scale of beings in the sublunary zones are the plants, the lower animals, men, the souls of the dead who have not yet ascended into the eternel superlunary spheres, and the dread elemental demons ${ }^{29}$. The demons are in reality the powers of Chance, which determine the irregular and disorderly movements of all sublunary beings ${ }^{30}$. In the spheres above the moon reside the astral deities and the souls of men who have achieved astral immortality ${ }^{31}$. Although these celestial beings are divine and eternal powers, superior to the contingent sublunary spirits, they are also hierarchically ordered, in the ascending scale of deified men, the

27 CIC., De Nat. Deor., II, 39 sq. Cf. DIOG. LAERT., VII, 139; Orphic Hymn, V, 4 Hermann.

28 POSIDONIUS et al., in DIOG. LAERT., VII, 143. This order may be called more properly pan-psychical, reflecting thereby the Chaldean motif presented in the text under the heading of 'The Astrological Role of the Planets'.

29 POSIDONIUS (Sextus Empiricus) in von ARNIM, Fragmenta, II, p. 303, 10 22. Although this passage is not clearly stated to be from Posidonius, BEVAN, op. cit., p. 105, ascribes it, with some question, to Posidonius; and I follow his lead. Cf. also the passage on Varro in AUGUST,, De Civit. Dei, VII, 6, Migne. Concerning the malign character of the elements, CUMONT (Astrology and religion, p. 122) says : «These elements were not only deified: they were themselves haunted by formidable powers; especially the zone of the air, which envelops the earth, was the chosen home of demons, kindly or malignant beings, who occupied the middle space and served as intermediaries between gods and men, superior to the latter, inferior to the former.» CHRYSIPPUS in CIC., De Nat. Deor., 1, 39, considers these elements as gods. On the beings who peopled the upper air, cf. PHILO, The Confusion of Tongues, IV, 173 sq., trans. F.H. Colson, LCL.

30 The Greek term here employed for Chance is $\tau$ ò $\alpha \dot{v} \tau o ́ \mu \alpha \tau o v ; v i d e$ CHRYSIPPUS (Alexander Aphrodisias) in von ARNIM, Fragmenta, II, p. 281, 34-38; cf. CIC., De leg., II, 28, trans. C.W. Keyes, LCL. - The notion of Chance among the Stoics is a tenuous idea; certainly $\tau v \dot{\chi} \chi \eta$ is excluded from

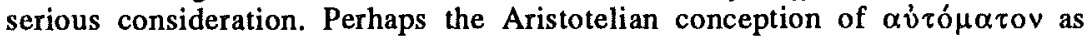
an indeterminate cause or spontaneity has some bearing on the Stoic idea; vide GREENE, op. cit.(n. 18), p. 320 sq., 325, and 423 n. 56; also FESTUGIÈRE, op. cit. (n. 22), p. 41; MURRAY, op. cit. (n. 11), p. 128 sq. - Cf. PHILO, On Providence, fr. II, 53, trans. F.H. Colson, LCL.

31 DIOG. LAERT., VII, 151. 
fixed stars, and the seven planets ${ }^{32}$. Being supreme among the gods, the planets are therefore the powers of divine Necessity 33 . Through their conjunction with the twelve fixed stars, they rule the entire macrocosm, determining its unity and destiny 34 .

Thus, the Stoic world picture is a vast material universe with no modes of being or life outside the field of the senses. The whole of reality is contained within «the envelope of fiery ether, one world, knit together by a natural sympathy between all the parts $35_{\text {». }}$

\section{The Planets}

Necessity. Presiding over the Stoic macrocosm are the divine planets. They are the gods par excellence, the rulers of heaven and earth $^{36}$. Of course Plato ${ }^{37}$, Aristotle ${ }^{38}$, and perhaps Pythagoras ${ }^{39}$,

32 CIC., De Republ., VI, 17-18. The eclectic character of Cicero's world view in 'Scipio's Dream' lends itself to an exposition of Neo-Platonism, as seen later in MACROB., I, 17-22, Comm. in Somn. Scipion., F. Eyssenhardt; W.H. STAHL (Macrobius : Commentary on the Dream of Scipio, New York, 1952 , p. 26) writes in his 'Introduction' that «Macrobius had used Cicero's text merely as a framework upon which to hang Neoplatonic doctrines gathered from his readings».

33 CIC., De Nat., Deor., II, 51-56 and 88 (Posidonius); cf. CHRYSIPPUS (Stobaeus) in von ARNIM, Fragmenta, II, p. 264, 18-21; PHILO, On Providence, fr. II, 50.

34 CIC., De Nat. Deor., II, 60 and 51-59. Cf. also CIC., De Divinat., II, 89; POSIDONIUS in DIOG. LAERT., VII, 139, says that 'the heaven' is the ruling of the world. Heaven here refers, I think, to the spheres of the planets and the fixed stars in which the deity (Providence or Necessity) has his seat; cf. ibid., 138. The contrast here between unity and destiny may appear more clearly in the following section under the term 'Necessity'. At this point, unity may be described as the causal relation existing between the parts of the macrocosm, involving both mechanistic and free (psychical) causation. Destiny, on the other hand, his the active force, conscious purpose, which shapes and determine the character of unity.

35 BEVAN, op. cit., p. 114.

36 MURRAY, op. cit., p. 134 sq.

37 PLAT., Epinom., 983 e, 984 d-e; Leg., 899 b, 931 a; Tim., 39 e, 40 b and d; Rep., 508 a-b.

38 ARISTOT. (Stobaeus) in DIELS, Doxographi, p. 450, 9-16.

39 PYTHAGOR. (Epiphanius) in DIELS, Doxographi, p. 589, 4-6; DIOG. LAERT., VIII, 27; cf. also the Anonyme Pythagoreer in DIELS, Vorsokratiker, I, 449,16 sq. 
as well as Aeschylus ${ }^{40}$ and Euripides ${ }^{41}$, believe that the planets are divine and eternal beings ${ }^{42}$. But this belief does not seem to have much religious intensity, until Posidonius of Apamea ${ }^{43}$, under the influence of Chaldean astrology, introduces to the Stoa the divine cosmic rule of the seven planets ${ }^{44}$. Posidonius' theological interest in the planets springs from his concern for $\operatorname{man}^{45}$. His hope is to provide man with a system which will serve as a practical guide of life, enabling him to feel at home in a strange and hostile universe ${ }^{46}$. The planets are not simply distant powers which regulate mechanically the cosmic process ${ }^{47}$. They are deities who take an interest in

40 AESCH., Agam., 4-7; 364-366.

41 EUR., Hippol., 530-534.

42 DODDS, op. cit. (n. 11), p. 261, considers the divinity of the planets in Plato as "a piece of imaginative decoration».

43 Posidonius was a Stoic philosopher, born in Apamea, Syria, about 135 B.C., and died at Rhodes, about 51 B.C. In 95 B.C. (?), he became by adoption a citizen of Rhodes, where he taught until his death. Cicero, in his young days, came to Rhodes to study philosophy under him. "A man of immense knowledge and strong religious emotions, he moved the Stoa in the direction of Oriental mysticism»; MURRAY, op. cit., p. 152, n. 52. Vide BEVAN's excursus (op. cit., p. 85-118) on Posidonius, and also a brief comment in SCOTT, Hermetica, III, 112.

44 MURRAY, op. cit., p. 133 sq., argues that the belief in the divinity of the planets did not reach much religious intensity until it was reinforced by two alien influences, viz., the ancient worship of the sun and the adoration of the seven planets (and it has been argued, vide $\mathrm{n} .10$, that these influences stem from Chaldean astrology and astral worship). - CUMONT, op. cit. (n. 29), p. 84, states that it was Posidonius who was responsible for the alliance of Semitic tradition with Greek thought and that «above all it was due to him that astrology entered into a coherent explanation of the world, acceptable to the most enlightened intellects». Although BEVAN (op. cit., p. 116) remarks that CUMONT has overstated Posidonius' incorporation of Syrian religious traditions in Stoic philosophy, he does agree essentially with CUMONT's thesis. L.R. TAYLOR (Divinity of the Roman Emperor, Middletown, 1931, p. 52) also recognizes Posidonius' influence in spreading astrological ideas among the Stoa. It must be admitted here, however, that Posidonius becomes a shadowy figure and that what is frequently attributed to him might simply be accretions brought into Stoicism by his disciples. When, therefore, his name appears in this chapter in connection with ideas which are not explicitly ascribed to him in the sources, it will be an eponym for Posidonian Stoicism.

45 CIC., De Nat. Deor., II, 154 sq. Cf. also SCOTT, Hermetica, IV, 401.

46 BEVAN, op. cit., p. 98 sq.

47 The Epicurean VELLEIUS in CIC., De Nat. Deor., I, 52 sq., ascribes to Stoic theology this mechanical view of Necessity and describes it as an irksome bondage which maintains the courses of the stars. 
man, shaping and determining through divine counsel human destinies. In this capacity they are truly powers of Necessity 48 . But Necessity is not the natural mechanistic principle of determinism of early Stoic tradition ${ }^{49}$. It is Destiny or Fate, something less physical, more like conscious purpose - almost identical with Providence 50 . As Murray puts it :

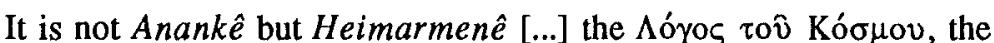
Nov̂ $\Delta$ tós, the Reason of the World or the mind of Zeus, rather difficult to distinguish from Pronoia or Providence which is the work of God and indeed the very essence of God. ${ }^{51}$

Necessity, then, is not an external and alien force. It is the internal power of reason pervading the whole; it is the natural sympathy which unites all things to one another, $\dot{\eta} \sigma v \mu \pi \alpha \dot{\theta} \theta \varepsilon 1 \alpha \tau \hat{\omega} v$ ó $\lambda \omega v^{52}$.

48 Cf. PHILO, The Migration of Abraham, 179. Cf. also ibid. 181. - Although 'these men' refer to the Chaldeans, F.H. COLSON indicates in his notes to PHILO's Allegorical Interpretation, trans. G.H. Whittaker, LCL, I, p. 478, that this developed thought is Stoic.

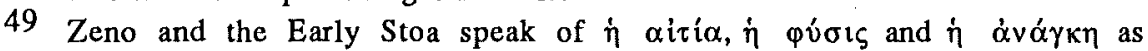
equivalent to ei $\mu \alpha \rho \mu \varepsilon \varepsilon^{\prime} \eta$ (Stobaeus and Plutarch) in DIELS, Doxographi, p. 322 ; cf. (Plutarch) in DIELS, Doxographi, p. 324, as the teaching of the Stoics in general on Necessity. Vide CHRYSIPPUS (Alexander Aphrodisias) in von ARNIM, Fragmenta, III, p. 165, 15-18; CIC., De Nat. Deor., II, 73-168; DIOG. LAERT., VII, 138.

50 Here, as in the Chaldean astrology, an inconsistency appears which is difficult, if not impossible, to harmonize. Commenting on this problem, GREENE (Moira, p. 338) states : «At one time Stoicism seems to be pantheism; at other moments, as in the Hymn of Cleanthes, it is a theistic religion"; vide CLEANTHES (Stobaeus) in von ARNIM, Fragmenta, I, p. 537. In DIOG. LAERT., VII, 135 sq., God in Stoic terms is referred to as Reason, Destiny, Zeus and many other names. H.A.A. KENNEDY, St. Paul and the MysteryReligions, New York, 1913, p.9, concludes that «Here, therefore, there is presented a religious view of the world, based on a virtual monotheism, which can be traced back to Posidonius' reshaping of the ancient astral worship of Babylon by means of Stoic-Platonic conceptions.» This monotheistic aspect is seen in CIC., De Republ., VI, 26. Yet, again, a polytheism appears in CIC., De Nat. Deor., II, 51-58, 77-80, and 154; and his henotheistic aspect, in DIOG. LAERT., VII, 139, where it is said that the ruling god is ether (Antipater of Tyre), the purer part of ether (Chrysippus), the sun (Cleanthes), and the heaven (Posidonius). Cf. CUMONT, op. cit., p. 159.

51 MURRAY, op. cit., p. 129-130. Vide SCOTT, Hermetica, III, 424 sq., on the Stoic conception of Heimarmene; also A. DIETERICH, Abraxas, Leipzig, 1891 , p. 73-76.

52 CHRYSIPPUS (Cleomedes) in von ARNIM, Fragmenta, II, p. 170, 32; cf. CIC., De Divinat., II, 34, 124, and 142. Also cf. PHILO, On the Creation, I, 
And the planets are the chief gods of this divine reason, interpreting

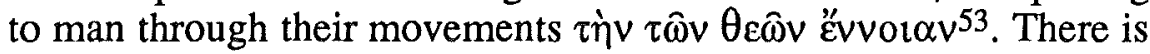
no need for man to fear them. It is only necessary that he recognize them as gods of reason and purpose and relate himself properly to them, by complying with that divine $\varepsilon i \mu \alpha \rho \mu \varepsilon v \eta, \sigma v \mu \pi \alpha \theta \varepsilon \iota \alpha$ or $\pi$ póvor $\alpha$, whose service is perfect freedom ${ }^{54}$. Thus he avoids suffering and overcomes his sense of cosmic estrangement.

Astral divination. As an aid, however, to the avoidance of improvident action and to the attainment of Stoic wisdom ${ }^{55}$, Posidonius includes in his system the 'science' of astral divination : the belief that the future can be read in the stars by those who are skilled to do so ${ }^{56}$. The traditional Stoic belief in the sympathy of all creation provides him with a ready-made basis for this mantic art ${ }^{57}$. Yet, he wishes to establish this belief through scientific means. Traveling to Gades ${ }^{58}$, he there observes the sympathetic relation between the phases of the moon and the Atlantic Ocean and concludes that the tides of the Ocean are dependent upon the lunar cycle ${ }^{59}$. If the moon can regulate the tides of the mighty Atlantic, it

113 and 117 sq., trans. G.H. Whittaker, LCL; PHILO, Allegorical Interpretation, 8; EPICTETUS, I, 14, trans. W.A. Oldfather, LCL.

53 DIOD., II, 30,4, the Chaldean teaching. Cf. CIC., De Nat. Deor., II, 54 and 77 sq.; PHILO, Allegorical Interpretation, 8-9; On the Creation, 113. Vide, on the basis of PHILO's, On the Migration of Abraham, 179 and 181, KNOX, St. Paul and the Church of the Gentiles, p. 51. - Vide also PHILO, The confusion of Tongues, 173-174.

54 MURRAY, op. cit., p. 130.

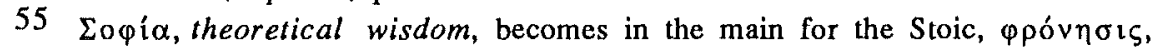
practical wisdom; cf. DIOG. LAERT., VII, 92 sq. Emphasis is placed upon the

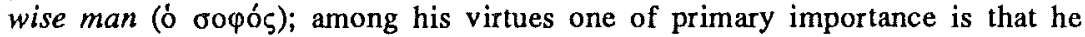
is a worshipper of the gods. He knows how to serve the gods, is acquainted with their rites, makes sacrifices to them, and offers prayers, asking good things from them; DIOG. LAERT., VII, 119-124. Cf. PHILO, Every Good Man is Free, IX, 41-42, trans. F.H. Colson, LCL, where the wise man stands in close relation with the celestial gods. Posidonius' emphasis on astral divination as a part of Stoic wisdom reflects the astral doctrine of $\sigma 0 \varphi i \alpha$ in PLAT., Epinom., 976-977, passim.

56 CIC., De Divinat., I, 6 and 125-127; cf. Cicero's negative assertion (ibid., II, 88), which attests to astral divination among the Stoics; DIOG. LAERT., VII, 149. For a limited influence of astral divination (perhaps from Stoic teaching), cf. PHILO, On the Creation, 58-59 and 113.

57 CIC., De Nat. Deor., II, 19; EPICT., I, 14; DIOG. LAERT., VII, 140 and 149.

58 STRAB., Geogr., 173 sq., trans. H.L. Jones, LCL.

59 Cf. Philo's (Allegorical Interpretation, I, 8 sq.) brief panegyric on the hebdomad, where the moon is considered to be the most sympathetic to the 
must also be able to control the tides in the affairs of men ${ }^{60}$. It seems, therefore, only a natural illustration of cosmic sympathy that the movements of the planets should be bound up with the fortunes of man. And nothing is more natural than to suppose that «the wisdom of the Chaldeans had indeed discovered in the movements of the planets through the fixed stars the signs which foretold, to those who could read them aright, the future destinies of the world, and indeed of every individual in the world; for all were bound together by that natural 'sympathy', which was also providence and fate an the will of God ${ }^{61}$ ». Hence on the grounds of cosmic sympathy Posidonius accepts the Chaldean 'science' of astral divination. But he strengthens it with Platonic psychology62. As a result, man and the planets become vitally related.

Like the universe, man is a quaint materialistic dualism, a microcosm composed of body and soul ${ }^{63}$. The body, however, is earthborn, being simply a composite of the four sublunary elements. The soul, on the other hand, is a fragment of the ethereal planets and therefore divine ${ }^{64}$. Thus because of this vital relation, man is able with greater certainty to discern through the dispositions and

earth of all the planets; also PHILO, The Special Laws, II, 140-161, where the same theme is developed. On the divine nature of the moon from the Stoic point of view, vide CIC., De Nat. Deor., II, 19, 50, 103, and 119.

That is to say, man under sublunary conditions, harassed constantly by the elements, rises and falls according to the necessities of the moon; cf. MURRAY, op. cit., p. 141, and KNOX, op. cit. (n. 53), p. 63. This sort of sympathetic relation holds not only in the case of the moon but also in the case of each of the other planets.

61 KNOX, op. cit., p. 63.

62 Cf. PHILO, On the Creation, 117 sq.; BEVAN, op. cit., p. 100 sq.; E. ROHDE, Psyche, trans. W.B. Hillis, London, 1925, p. 502, 518-519; DODDS, op. cit. (n. 11); COPLESTON, op. cit. (n. 9), I, p. 423. N.B. Greene's rejection (Moira, p. 354) of this view of Posidonius.

63 Cf. PHILO, On the Creation, 69, 82, $146 \mathrm{sq}$., for the macrocosm-microcosm analogy of Stoicism. N. B. ibid., 117 sq., where the sympathy of the macrocosm and microcosm is based on the correspondence between the seven planets and the seven lower parts of the soul; cf. the Stoics (Plutarch) in DIELS, Doxographi, p. 410, 25 sq. Also vide ROHDE, op. cit., p. 497 sq.

64 CIC., De Republ., VI, 15. Cf. Hipparchus' statement in PLIN., Nat. Hist., II, 95, trans. H. Rackham, LCL; also CIC., De Leg., I, 20-27. The notion of the

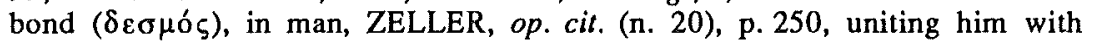
the superlunary part of the macrocosm, derives from PLATO, Tim., $31 \mathrm{c}$. As KNOX [op. cit. (n. 53), p. 65] puts it: «By means of this amalgamation of the Timaeus with the older Stoic tradition, it became possible to combine a system of transcendental monotheism with the pantheism of the early Stoa,» 
movements of the planets his own future, whether good or ill, and to direct his course accordingly.

Astral mysticism. Astral divination, however, is only a part of wisdom. It merely provides a way of knowing about the future ahead of time. It offers no control over or relief from what the future may bring. According to early Stoic tradition, man is alone in his struggles with Fortune and Fate. His lot is to endure all things until death, when he is absorbed again into the cosmic fire from which he came ${ }^{65}$. Thus, facing the decrees of fate nobly is the part of wisdom. Concerned, however, with man's predicament, Posidonius leads Stoicism to a belief in astral mysticism : an esthetic contemplation of the heavens by which man enters into mystic communion with the divine stars ${ }^{66}$. The planets are no longer merely cosmic rulers who impose on all the consequence of fate or simply far-off visible gods whose movements through the heavens reveal the counsel of the gods. They are beneficent personal deities who are accessible to their devotees through direct communion ${ }^{67}$. This divine encounter rests on a mystical psychological experience. The human soul, being a particle of the planetary nature, is kin to the gods; and the divine reason which enlightens the luminaries also animates man ${ }^{68}$. Esthetic contemplation of the heavens thus becomes a religious contemplation ${ }^{69}$. It arouses in the devotee a 'cosmic emotion' which lifts his soul in ecstasy and enthusiasm into the presence of the starry choir ${ }^{70}$. Here he gains divine strength to overcome sublunary ills

65 CHRYSIPPUS (Arius Didymus) in von ARNIM, Fragmenta, II, p. 223, 20; also in DIELS, Doxographi, p. 471, 19-20, cited here simply as a teaching of the Stoa. Cf. PLIN., Nat., Hist., VII, 55.

66 SENEC., On Benefits, IV, 23, trans. A. Stewart, London, 1887, asserts that, in spite of other benefits deriving from our dependence on the sun and moon and the planets, these stars arouse our wonder by their beauty and demand our adoration by their majesty. Cf. especially CUMONT, op. cit. (n. 11), p. 139149; FESTUGIËRE, op. cit. (n. 22), p. 117; DODDS, op. cit., p. 247 sq.

67 As mentioned earlier, CUMONT, Astrology and Religion, p. 158 sq., calls attention to a fundamental inconsistency here: that astrology in all its developments professes to be an exact science, but actually remains a priestly theology.

68 CIC., De Republ., VI, 13 and 15.

69 CUMONT, op. cit., p. 144 sq. and 200 sq.; FESTUGIÈrE, op. cit., p. 117 118.

70 Cf. LUCIAN., De Civil. Bell., I, 45-46, trans. J. D. Duff, LCL; IUL., Orat., IV, 130, trans. W. C. Wright, LCL; St. PAUL, I, Corinth., $12: 2-4$, refers to one (perhaps himself) as having been snatched up into the third heaven and into 
and receives insight into the mystery of the ascent of the soul at death into the planetary spheres. Thus man acquires through 'cosmic emotion' what he could never acquire through reason alone, viz., the eschatological hope of astral apotheosis ${ }^{71}$. Astral mysticism, therefore, modifies the obdurate character of the planets, making them evangels of salvation and hope rather than bearers of suffering and despair. Under their patronage man can anticipate at death personal immorality among their spheres ${ }^{72}$. Knowledge of this mystery is indeed the fullness of wisdom ${ }^{73}$.

Department of Philosophy

B. McMINN

University of Alabama

Alabama 50020

U.S.A.

Paradise, where he heard words unspeakable; cf. also Galat., 1 : 12-18; Acts, 9: 1 sq. Vide on St. Paul's and Plotinus' astral apotheosis, MURRAY, op. cit., p. 143; re 'ecstasy' and 'enthusiasm', ibid., p. 131. KENNEDY (St. Paul

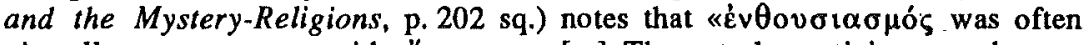

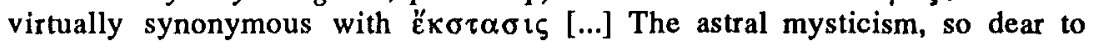
Posidonius employs the method of absorbing contemplation. By its means, communion with the divinity is possible of attainment."

71 CUMONT, Les religions Orientales, p. 265, n. 91; DIETERICH, Eine Mithrasliturgie, p. 179 sq. Cf. PLAT., Epinom., 986 c.

72 CIC., De Republ., VI, 13, 16, and 19. Cf. a passage of Stoic doctrine, attributed by BEVAN, op. cit., p. 108, to Posidonius (Sextus Empiricus) in von ARNIM, Fragmenta, II, p. 223-224 and p. 321, 8-18, where the souls of the wise and good man are raised to the stars.

73 Cf. again PLAT., Epinom., 992 a-b. This notion of wisdom may be compared somewhat with Socrates' idea of philosophizing, in PLAT., Phaed., 66c-68b; J. BURNET ed., Plato's Phaedo, Oxford, 1953, as a kind of dying, i.e., death being thought of here as the separation of the soul from the body, so that the soul in its purity might live an unemcumbered life with God; cf. also T. WHITTAKER, The Neo-Platonists, p. 127. 